\title{
PROBLEMS ENCOUNTERED BY TEENAGE MOTHERS IN THE SOUTHERN HHO-HHO REGION OF SWAZILAND
}

\section{Ms Lovegirl S Dlamini}

BA Cur; Honours BA Cur; MA Cur

MA (Cur) student, Department of Health Studies, University of South Africa

\section{Mrs Martie M van der Merwe}

BA Cur; Honours BA Cur; MA Cur

Lecturer, Department of Health Studies, University of South Africa

Corresponding author: vdmermm@unisa.ac.za

\section{Dr Valerie J Ehlers}

B Soc Sc (Nursing); Honours BA (SS) (Psychology); BA Cur; Honours BA Cur; MA Cur; D Litt et Phil; Diploma in Development Studies

Senior Lecturer, Department of Health Studies, University of South Africa

Keywords: Hho-Hho region, Swaziland; teenage mothers; support systems; teenage motherhood problems

\section{SUMMARY}

A qualitative, explorative, descriptive and contextual research approach was followed to study the problems experienced by teenage mothers in the southern Hho-Hho region of Swaziland. The findings of transcribed in-depth individual interviews indicated that the major problem encountered by the participants was the lack of knowledge, advice and emotional support before, during and after their pregnancies. Parents, partners, peer groups, health personnel, teachers, church leaders and communities failed to empower the teenage mothers with knowledge and skills to prevent pregnancy or to facilitate motherhood. This lack of support impacted on the social, cultural, economic, spiritual and emotional dimensions of the teenage mothers. These effects caused problems for the teenage mothers, their families and their communities which could be addressed by multi-disciplinary approaches and intersectoral collaboration.

\section{OPSOMMING}

'n Kwalitatiewe, eksploratiewe, beskrywende en kontekstuele navorsingsbenadering is gevolg tydens die studie van probleme wat deur tienermoeders in die suidelike Hho-Hho gebied van Swaziland ondervind is. Die bevindinge van getranskribeerde in-diepte persoonlike onderhoude het aangetoon dat die grootste probleem wat die deelnemers ondervind het, toegeskryf kan word aan 'n gebrek aan kennis, raad en emosionele ondersteuning voor, gedurende en na hulle swangerskappe. Ouers, metgeselle, portuurgroepe, gesondheidspersoneel, onderwysers, kerkleiers en gemeenskappe het in gebreke gebly om hulle met kennis en vaardighede te bemagtig om swangerskappe te voorkom of moederskap te vergemaklik. Die gebrek aan ondersteuning het 'n impak gehad op die sosiale, kulturele, geestelike, ekonomiese en opvoedkundige dimensies van die tienermoeders. Hierdie gevolge het probleme vir die tienermoeders, hulle gesinne en hulle gemeenskappe veroorsaak wat deur multidissiplinêre benaderings en intersektorale samewerking aangespreek kan word. 


\section{INTRODUCTION}

According to Swaziland's Motherhood Audit Report (1997), out of the 6756 babies delivered at health services in the Hho-Hho region during 1996, 12 were delivered by teenage mothers aged $10-14$ years; and 1520 were delivered by teenage mothers aged 15-19 years. Thus teenage mothers (aged 19 or younger at the time of the baby's birth) comprised $22.67 \%$ of all women who delivered babies in this area during 1996. Although no health services exist in Swaziland for the special needs of the adolescent and adolescent mothers the above-mentioned statistics indicate the importance for such a service for this vulnerable group. The most important developmental task of adolescence is inter alia to develop into mature adults who can establish mature relationships with the opposite sex, prepare for a vocation, become economically independent and prepare for marriage. The abrupt assumption of parental responsibilities precludes the successful resolution of teenage development and may have adverse effects on the future life of the teenage mother. The vicious circle of early motherhood, poor education and poverty, leading to more children and greater poverty, has been well documented in many countries. To attempt to make a difference in the lives of the teenage mothers and to break the above-mentioned vicious circle, it is important to determine what problems the teenage mothers in the Hho-Hho region of Swaziland are experiencing, as nothing has been documented of the unique problems encountered by teenage mothers in this area. Once the problems experienced by the teenage mothers in this region were known, recommendations could be made to improve the health services and support systems to address the unique problems of the teenage mothers in the southern Hho-Hho region of Swaziland.

\section{PURPOSE OF THE RESEARCH}

The purpose of the research was to explore and describe the problems experienced and reported by the teenage mothers themselves. This information could then form the basis for recommendations to enhance the quality of life of teenage mothers and their children in the southern Hho-Hho area of Swaziland.

OBJECTIVES OF THE RESEARCH
The objectives of this research focused on the southern Hho-Hho region of Swaziland and attempted to:

- identify problems encountered by the teenage mothers;

- explore and describe the teenage mothers' support systems;

- recommend means and ways to address teenage mothers' problems; and

- make recommendations for further research in this field.

\section{RATIONALE OF THE RESEARCH}

It was on the basis of the following discussion that the research area was selected:

- Teenage mothers experience unique problems because they are often not physically, socially, culturally, emotionally, spiritually, economically and educationally ready to deal with motherhood.

- Teenage mothers frequently do not have the necessary support or they do not make use of the available support systems in the southern HhoHho region of Swaziland to help them deal with their problems.

- Knowledge obtained from the research findings could be implemented to improve the services offered by the health care system to the teenage mother thereby meeting the unique needs of the teenage mother more realistically.

\section{STATEMENT OF THE PROBLEM}

Little was known about the problems that the teenage mothers in the southern Hho-Hho region of Swaziland were experiencing. Before any health service or support service could be planned for the teenage mothers, it was essential that an in-depth study, to understand their unique problems as they experience it, be conducted.

From this problem statement the following research questions were derived:

- Do the teenage mothers in the Hho-Hho region of Swaziland experience any physical, social, cultural, emotional, spiritual, economic and educational problems, and how do they experience it?

- Which support systems do the teenage mother make use of in the community?

- What recommendations can be made that would 
enable the health care services in the southern Hho-Hho region of Swaziland to help solve the problems experienced by teenage mothers?

\section{RESEARCH METHODOLOGY}

\section{Research design}

As this research investigated the problems experienced by teenage mothers on a daily basis it adopted the qualitative paradigm to gain insight through discovering meaning, exploring the depth, richness and complexity inherent in the daily lives of teenage mothers (Burns \& Grove, 2001:61).

\section{This research was:}

- descriptive as detailed pictures of the problems of the teenage mothers, as experienced by themselves, were described;

- explorative as it explored the problems of teenage mothers regarded to be a relatively unknown phenomenon in the southern Hho-Hho region of Swaziland; and

- contextual as it was executed within the context of teenage motherhood in the southern Hho-Hho region of Swaziland.

\section{Population and sample}

The research population comprised all teenage mothers aged 19 or younger living in the southern HhoHho region of Swaziland. The sample comprised those teenagers who met these criteria and who were willing to be interviewed by the researcher. The selection criteria for inclusion in the purposive sample included that each participant had to

- be a female between the ages 10 and 19 years, in order to be a teenager;

- have at least one child to be a mother;

- be single because married teenage mothers might have more and/or different support systems than single or unmarried teenage mothers;

- be willing to take part in the research and to be interviewed by the researcher; and

- reside in the southern Hho-Hho region of Swaziland to be geographically accessible to the researcher.

\section{Research instrument}

In-depth individual interviews were conducted to obtain in-depth knowledge of the problems experienced by the teenage mothers. It also allowed the teenage mothers to share information without restrictions imposed by literacy problems, and to elaborate on certain problems in their own words. It therefore enabled the researcher to obtain in-depth, dense descriptions enhancing the researcher's understanding of each participant's world (Babbie, Mouton, Vorster \& Prozesky, 2001:287).

An interview schedule was used to allow the participants to supply answers in their own words. The interview questions were translated into siSwati and checked by a professional nurse proficient in both English and siSwati to convey the same meanings in both languages. This interview schedule contained only the following broad questions pertinent to the research problem:

- What physical/health problems have you experienced as a teenage mother?

- What social problems have you experienced as a teenage mother?

- What cultural problems have you experienced as a teenage mother?

- What emotional problems have you experienced as a teenage mother?

- What spiritual problems have you experienced as a teenage mother?

- What economic problems have you experienced as a teenage mother?

- What educational problems have you experienced as a teenage mother?

- What support systems have you used as a teenage mother?

The interviews were conducted and transcribed in siSwati, the transcriptions were then translated into English. Hard copies of both the siSwati and English transcriptions were checked by two independent researchers, proficient in both languages. Minor changes were implemented to the English version as a result of their inputs.

The conceptual framework adopted for this study was the Whole Person Theory, as described by the Oral Roberts University, Anna Vaughn School of Nursing 
(1990:136-42). Consequently the dimensions described in this theory provided the basis for the interview schedule to study the problems encountered by teenage mothers in the southern Hho-Hho region of Swaziland holistically.

\section{Ethical aspects}

Permission to conduct the study was obtained from Swaziland's Ministry of Health, authorities at the HhoHho regional health office and Mbabane public health staff. Written consent was obtained from the authorities to conduct the research in two comprehensive community health clinics in the Hho-Hho region of Swaziland. Each possible participant was informed about the purpose of the research and requested to participate by granting a personal interview with the researcher. Written consent was obtained from each participant after she was informed about her rights. No harm was done to any participant, no remuneration was paid for participation and no rights were compromised by declining participation. Each participant remained free to withdraw her participation at any stage or to refrain from answering any specific question. Although each participant signed consent prior to each interview, these documents were kept separately from the transcriptions and translations of the interviews. The researcher was the only person who could link any consent form to a specific interview. This information was destroyed after the completion of the research report.

\section{Analysis of the data}

The transcripts of the in-depth interviews were prepared for the analysis by the QRS NUD*IST computer programme as follows:

- The text was divided to form individual concepts and converted into an ASCII-DOS file.

- A single code was allocated to each theme, such as physical problem or emotional problem.

- These themes were defined to clarify which attributes should be classified under a certain theme.

- Sub-themes were identified and defined using the QRS NUD*IST computer programme.

- These steps were repeated until small pieces of information (sentences or paragraphs) could be identified which could stand alone (De Vos, Strydom, Fouché, Poggenpoel \& Schurink,
1998:48)

- The analysis and interpretation implied that all respondents' information were combined under each relevant category by using the QRS NUD*IST computer programme.

- This process continued until all the data were dealt with.

- The findings of all the interviews were compared and discussed with the supervisors and the statistician.

- The procedures followed to arrive at conclusions and to verify the comparison of the data included: identifying patterns and themes; clustering of the data; looking for negative (contrasting) cases; checking the results with the respondents (De Vos et al. 1998:340).

The following reasoning strategies were used to describe the chain of events:

- Analysis - This reasoning strategy divides the complex whole into parts, code and define the parts.

- Synthesis - This process identified relationships between concepts and categories.

- Bracketing - The initial literature review was done to familiarise the researcher with problems encountered by teenage mothers in different parts of the world, and to become knowledgeable about research designs used to investigate these problems. During the interviews and analysis of the data the researcher bracketed preconceived ideas and attempted to understand all the facets of the problems encountered by teenage mothers in the southern Hho-Hho area of Swaziland as told by these participating teenagers themselves. Only broad questions were asked and no efforts were made to ask questions which could confirm or refute previously reported research results.

- Intuiting - Bracketing enabled the researcher to focus on the problems encountered by teenage mothers as experienced and as told by the teenage mothers during the interviews. Intuiting required absolute concentration and complete absorption with the data obtained (De Vos et al. 1998:337). Intuiting was achieved by reading and rereading the transcriptions many times before attempting to identify specific sub-themes, relevant to each theme from the structured interview schedule. The QRS NUD*IST program was of great assistance as it helped to systematise the analy- 
sis of the data, enhancing rigour during the data analysis process without sacrificing the relevance of the data.

\section{Trustworthiness}

The criteria used to evaluate the trustworthiness of the research findings in this research were credibility, transferability, consistency and neutrality.

- Credibility: The truth value of the research was the discovery of the lived experience as perceived and reported by the teenage mothers in the HhoHho region of Swaziland. The views of each respondent were recorded and transcribed and translated as adequately as possible. The truth value of the analysed data was subjected to member checking by the participant teenage mothers and by persons familiar with the problems of teenage mothers in the Hho-Hho region of Swaziland. These individuals agreed that they recognised the description of the problems experienced by the teenage mothers as presented by the data analysis (Babbie et al. 2001:287). As the analysis of the data was done by computer using the QRS NUD*IST computer programme, the decision trail can be audited for quality assurance purposes.

- Transferability: The findings of this research will not necessarily be applicable to other communities and settings and the findings can therefore not be generalised to the teenage mothers throughout Swaziland. The same results could be obtained if a similar study was done in the same setting. Attempts were made to present sufficient descriptive data to allow comparisons with data from future studies in the same area on the same topic (Babbie et al. 2001:276; De Vos et al. 1998:350).

- Consistency: The same findings would be found if the study was to be replicated with teenage mothers in a similar context. The interviews with teenage mothers generated similar findings. Interviews were conducted and analysed until data saturation was reached, when no further new themes or new sub-themes could be identified and when no further novel data could be categorised under any theme or sub-theme because the same data kept on reappearing from the analysis of sub- sequent transcribed interviews.

- Neutrality: The following steps were taken to ensure neutrality and increase the trustworthiness of the research findings.

- A relaxed atmosphere was created in which the participant felt free to share her perceptions, problems and experiences with the researcher.

- Enough time was allocated to each interview so that no participant was pressurised to provide answers within a specific time limit but could portray her everyday lived experiences from her unique perspective.

- The participants, as well professional nurses working with teenage mothers, evaluated the findings and agreed with the research results.

- Although a literature review was conducted, it was only done to help the researcher to ask appropriate questions.

- The truth value and applicability of the findings was an indication that neutrality was achieved (De Vos et al. 1998:350).

\section{RESEARCH RESULTS}

The findings of the interviews indicated that the teenage mothers in the southern Hho-Hho region of Swaziland experienced problems in almost all the dimensions of a holistic human being. However, the most important problems related to the lack of information from significant others (ignorance in all dimensions) as well as the lack of support from individuals and institutions.

It must be noted that it was difficult to separate the problems completely as they were intertwined. The most important problems experienced by the teenage mothers were in order of importance: ignorance and lack of support which caused immense emotional problems and left them feeling devastated, fearful, lonely, humiliated, frustrated and unhappy. The next group of problems in order of importance which impacted on their lives were educational problems, social and cultural problems, financial problems, and to a lesser extent spiritual problems. The teenage mothers reported no physical problems during pregnancy, birth and post partum. 
Table 1: Identified themes and their definitions obtained from the in-depth interviews relating to the problems experienced by teenage mothers in the southern Hho-Hho region of Swaziland

\begin{tabular}{|c|c|}
\hline Main themes & Definitions \\
\hline 1. Biographical information & $\begin{array}{l}\text { The personal information about the teenage mother and } \\
\text { significant others. }\end{array}$ \\
\hline 2. Physical problems & $\begin{array}{l}\text { The difficulties the teenage mother has experienced through } \\
\text { becoming and being a teenage mother related to her body and } \\
\text { physical health status. }\end{array}$ \\
\hline 3. Social problems & $\begin{array}{l}\text {... dealing with mutual relationships with significant others such } \\
\text { as parents, partner, family, peers; as well as with socialisation, } \\
\text { recreation and role models. }\end{array}$ \\
\hline 4. Cultural problems & $\begin{array}{l}\text {... related to standards of behaviours and doing things } \\
\text { determined by community beliefs, values and customs as well } \\
\text { as belonging to a specific institution. }\end{array}$ \\
\hline 5. Spiritual problems & $\begin{array}{l}\text {... towards faith and religious beliefs, the places where the } \\
\text { members of the community gather on a regular basis to } \\
\text { worship as well as with the people who gather to worship. }\end{array}$ \\
\hline 6. Emotional problems & ... in the dealing with intense mental feelings. \\
\hline 7. Economic problems & $\begin{array}{l}\text {... such as change in financial status, monetary contributions } \\
\text { received from other people, future expected financial status. }\end{array}$ \\
\hline 8. Educational problems & $\begin{array}{l}\text {... such as training and instructional problems that were } \\
\text { designed to equip her with knowledge and skills that would } \\
\text { shape her character and future. }\end{array}$ \\
\hline 9. Support systems & $\ldots$ institutions of which she made use of $\ldots$ \\
\hline 10. Ignorance & $\begin{array}{l}\text { Deficiencies in the informal and organised body of information } \\
\text { the teenage mother have on various matters, which are } \\
\text { affecting her life. }\end{array}$ \\
\hline
\end{tabular}

\section{Biographical information}

The teenage mothers who participated in the in-depth individual interviews were between 13 and 19 years of age. Most of them were still at school when they became pregnant, interrupting their education. Menarche occurred at an average age of 11 years. Their first sexual intercourse reportedly happened between the ages of 11 and 14 years. These teenage mothers were reportedly sexually active for an average of two years before they became pregnant. They had more than one sexual partner but did not consider the possibility of contracting HIV/AIDS. They were young and enjoyed being popular and in demand: "... I liked being in demand, I like competition with working women". Their partners were generally much older than themselves as reported by a teenage mother as follows: "I don't know his age, but he is older than me and he is working". These partners most probably have had sexual relationships before, however, these teenage girls believed that if they are involved in a steady relationship they are not at risk of contracting HIV/AIDS, 
as reported by one of the teenage mothers: "I have a steady partner" [and therefore I am not at risk of contracting HIVIAIDS]. In some instances where the teenage mother insisted that her sexual partner use a condom she was reminded of the submissive position a female has in that community, as reported by one teenage mother: "... he said even his wife (he) doesn't use plastics. [He said] who do I think I am to make him use condoms". Reportedly they were terrified of subsequent pregnancies. However, not one of the participants used any effective contraceptive method but continued to engage in sexual encounters, as illustrated by the following participant: "No, I never thought about contraceptive methods". This finding appeared to support Aretakis (2000:685) who maintains that in the United States of America (USA): "Teens often engage in behaviours that put them at risk for life-threatening diseases. For example, each year one quarter of both new HIV infections and newly identified sexually transmitted diseases [in the USA] occur among adolescents". Teenagers throughout the world seem to maintain a different world view from that of adults. Teenagers in Swaziland, similarly to those in the USA, might be described as feeling "... invincible and therefore do not anticipate any risk for the consequences related to their behaviours" (Aretakis, 2000:688). That is, they may not believe that sexual activity will lead to pregnancy, as two of the participants reported: "I never knew that I would become pregnant". "Ignorance is the cause" [of my pregnancy]. "When teens become pregnant, they do not believe that the negative outcomes they are advised of could come true. Many teens believe that they are unique and different and that everything will work out fine" (Aretakis, 2000:688).

\section{Educational problems}

Educational problems are problems experienced in the formal educational system whereas ignorance is the result of a lack of information or knowledge obtained usually informally in all the identified themes.

It was clear from the analysed data that once students became pregnant they were expected to leave school as expressed by two of the teenage mothers as follows: "... and [I was] ordered to pack and leave for good". "No, you usually do not go [back] to school .... [you] rather change schools". The interrupted education negatively impacted on their expectations for their own futures and those of their babies. The teenage mothers reportedly would have liked to finish school and would have liked their children to have a good education but they have reportedly lost faith in their own abilities to complete their education and to find good jobs. "I wish I could finish school. I would like to go to college and have a profession". "I would like my child] to have a university education". "I doubt myself now. I don't think that I will be able to finish school".

They need educational qualifications to improve their own lives as well as those of their children. However, they envisaged problems in achieving educational qualifications because they were no longer accepted by their peers or by their schoolteachers and they had the extra burden of caring for their babies. "They [the teachers] throw pregnant girls out of school, despise them. They scold you and expel you... [and you must] leave for good". "I have social problems now, ... I am now an outcast from my friends". "I am frightened. My future is affected by this. What is to become of me and my child?"

The participants were ignorant about many issues including puberty, pregnancy, labour, childcare and contraception. Apparently individuals and institutions responsible for the education and care of teenagers failed to empower them to prevent unplanned pregnancies as reported by some of the teenage mothers in this study. "Teachers did not tell us anything. We were never educated about sexual matters at school by the teachers. It is forbidden to discuss it". "The nurses were rude... Why didn't they tell us?" [Only] "when I was in hospital yes, the nurses gave me information".

Ignorance, aggravated by reported cultural taboos to talk about sex with one's parents, and by perceived peer group pressures to engage in sexual activities, caused unnecessary heartache to these young women. It also denied them the opportunity of making informed decisions about their futures, and about the futures of their children. "No, adults never told us anything, it is forbidden [to talk about sex]. It is not mentioned in the community either. It is taboo". "I heard about sex from my friends".

\section{Social and cultural problems}


The lack of support from the teenage mothers' families, friends, partners, communities, churches, nurses and teachers aggravated problems encountered by the teenage mothers who repeatedly referred to the lack of support during their interviews. This perceived lack of support made them feel devastated, frightened, lonely, humiliated, frustrated and unhappy. None of the teenagers mentioned any support received from any professional, institution, service or person who could counsel them, as illustrated by one of the teenage mothers: "You cannot ask them anything. They will not help you...".

Even the legal system let them down, as reporting rape cases was perceived to be futile, as nobody cared, not even the police. This should be seen in a serious light as it has been reported (in the USA) that $74 \%$ of women who had sexual intercourse before the age of 14 were coerced to do so (Moore, Driscoll \& Lindberg, 1998:10).

The teenage mothers also experienced social problems that must have contributed to their feelings of alienation. They hoped that their new found status as adults (once their babies were born they were no longer regarded as teenagers but as adults in the Swazi culture) in the community would make them happy, but it did not. They now had to mix with older members of the community which also contributed to the feeling that motherhood has caused them to be old before their time. Motherhood made them change into adults suddenly while their peers were still regarded to be children, expressed by a teenage mother as follows: "[l feel] old. Funny, it makes me feel old".

They did not fit into any group in the community, sharing no interests with the older women. They were also no longer accepted by their peer groups and denied access to the Swazi cultural maiden groups who take part in the annual reed dance festival, where Swazi men can select their (virgin) wives. "... that I can no longer be a maiden, I'm already out of the group. It is a pride to be a girl with no child and still belong to the maiden traditional group". They were not hopeful that they would find good husbands as Swazi men preferred marrying virgins and might be deterred from marrying women with children. The teenage mothers indicated that Swazi men generally wanted the privilege of premarital sex without assuming responsibili- ties for the possible consequences. "We [the women] are taken for granted in everything. We can't ask anything". "Men, they do what they want. Giving in, [is what girls must do] he always has the final word". "Men are always better than girls. They are the masters...".

Swazi society and culture awards men a higher status than women, leaving Swazi women few choices, and Swazi unmarried mothers' choices are even more limited than those of unmarried women without children. These teenage mothers' experiences are supported by Dlamini (2000:75-76) who describes the lives of a brother and sister growing up in the same Swazi family encountering opposing social sanctions, based on gender, for the same behaviour. While the brother would be praised for his ability to date more than one girl simultaneously, the sister would be severely reprimanded for such misbehaviour as it could decrease the bridal price ("Iobola") which the father could get from her future husband. "If this young woman falls pregnant before marriage, she becomes a disgrace to the family... a child born out of wedlock is called by bad names ... the young woman herself ends up being called lijikamlente ('the one who just throws her leg'), umjende-vu ('something that may not be enjoyed by anyone') or libondza-lisuta ('the one whose system has become loose'). These insulting expressions are used to warn every girl ... not to follow in the footsteps of the unfortunate young woman who has failed to conform to the prescribed norms" (Dlamini, 2000:7576).

No teenage mother indicated that she sought termination of pregnancy services that remain illegal in Swaziland. No one mentioned anything about emergency contraceptives which could have saved her from becoming a mother if she had the knowledge to access these.

\section{Financial problems}

The teenage mothers were generally from poor families, but their motherhood status aggravated their financial problems. Most of the teenage mothers indicated that they were of the opinion that their poor financial status was their biggest problem and that more money might take care of all their problems. "My biggest problem is where to get money to cope. I have to struggle for the child's survival and my own. I need 
money the most". This finding correlated with that reported in the USA by Nord (1992:310) who found that a disproportionate number of teenage mothers (more than $75 \%$ ) were poor and had limited education.

The Swazi teenage mothers could not rely on financial support from the fathers of their babies. No teenage mother reported receiving any financial aid from the baby's father or from his family. Their parents, mostly their mothers, had to carry the financial burden of caring for the teenage mothers and their babies an added burden on the meagre resources with which most women in this rural part of Swaziland attempt to care for their families. "No. He does not give me any money". "My mother had to find odd jobs to help with the finances". For the more traditional Swazi families finances seemed to be less of a problem as they were used to coping with the adversities of life - often within the limitations of a subsistence economy. The families who were in transitional stages towards assuming more Westernised lifestyles were emotionally hardest hit by the motherhood of the teenagers, as these families fostered hopes for better futures for their children - shattered by teenage pregnancies. Teenage mothers from these reportedly transitional families verbalised and demonstrated more feelings of rebelliousness and frustration than those from the more traditional families. "I felt like I disappointed my parents and that I was a failure. I was actually devastated". "I often feel frustrated. My future is affected by this".

\section{Physical problems}

All the participants were healthy and no serious health problems were reported during their pregnancies, labour or puerperium periods. These findings were unexpected as most of the respondents only commenced visiting antenatal clinics during the third trimesters of their pregnancies. The most frequent reason provided for such late attendance was that the teenagers failed to recognise the signs and symptoms of pregnancy (concurring with the lack of information about pregnancy discussed under educational problems in this article), as expressed by two of the participants: "I felt funny, I was growing bigger. My stomach was funny and big, also my breasts. I did not know what was happening with me". "I think I was about six months pregnant when it was first confirmed" [at this clinic that
I was pregnant]. Conversely to these findings, Van Winter and Simmons (in Aretakis, 2000:694) maintain that financial costs, denial of pregnancy, transportation problems, fear of informing their parents about the pregnancy and disliking the health care providers' attitudes towards pregnant teenagers contributed to their late attendance of antenatal clinics. As researchers continue to report greater physical pregnancy-related risks for teenagers than for adults (Boult \& Cunningham, 1992:1; Hallerstedt, Pirie \& Alexander, $1995: 1139)$, this absence of physical problems among these teenage mothers cannot be explained without access to their obstetric records. One teenage mother indicated that she never attended the antenatal clinic during her pregnancy: "I never went to the clinic during the pregnancy. There was no need, I was not sick and it was a little far".

\section{Spiritual problems}

Some teenage mothers felt guilty because they let their parents down. Their perceptions that their communities rejected them and that people gossiped about them caused them to discontinue their church activities, aggravating their feelings of isolation and alienation. They knew that their church does not condone premarital sex and therefore did not risk being seen at church gatherings. They considered themselves to have sinned, not expecting forgiveness for their sins of engaging in premarital sex. They reportedly lost faith in God and in people on whom they wanted to rely but who did not provide much needed support to them.

The teenage mothers felt alone in their predicament and felt that nobody really understood what they were going through. They felt let down by the very people they trusted. They felt that as if they had already lived a lifetime through this experience of motherhood, which made them feel tired and much older than their years. None of the teenage mothers mentioned that a minister, pastor or any church officials visited them during these difficult times neither to comfort, counsel or support them nor to invite them back into the church community. [The church] "believe that you are bad [when you fall pregnant and are not married], they do not accept it". "This [feeling of guilt] will stay forever. It will not go away".

\section{CONCLUSIONS}


The major problem encountered by the teenage mothers of the southern Hho-Hho region of Swaziland was the lack of support which also entails the sharing of information from their families, peers, partners, communities, nurses, teachers and churches. The perceived lack of support impacted negatively on the social, cultural, spiritual, economic, educational, emotional and spiritual dimensions of their personalities and lived experiences; making them feel guilty, disgraced, lonely and unhappy. Unexpectedly no physical pregnancy-related problems were reported by the teenage mothers. The economic problems encountered by the teenage mothers were perceived as frustrating as their chances, those of their children and of improving their futures were affected. Perceived rejection by both peers and teachers, made it very difficult to resume their interrupted education, dooming these adolescent mothers to a lifelong lack of education, jobs and money to their own detriment as well as that of their children.

\section{LIMITATIONS OF THE STUDY}

The interpretation of the conclusions of the study, and the recommendations based on these conclusions, need to consider that the research was limited by:

- focusing on single teenage mothers in the southern Hho-Hho area of Swaziland, only implying that teenage mothers in other areas and those who are married might not necessarily encounter the same problems;

- using only in-depth interviews with teenage mothers willing to grant such interviews, implying that the problems of those unwilling to be interviewed remain unknown;

- the inability of the researcher to correlate each participant's information with her obstetric history as recorded by a clinic and/or hospital. This would have provided an impartial and factual check on the participant's reported physical problems or the absence thereof; and

- excluding the teenage fathers' participation in this research implying that their perceptions and experiences remain unknown.

\section{RECOMMENDATIONS}

The solutions to the holistic problems of the teenage mothers cannot be found in the activities of a single individual or service. The solutions can only be found through the co-ordinated effort of the multi-disciplinary and intersectoral team.

Any initiative planned or programme implemented should have the approval and backing of government and should be closely monitored by authorities to ensure that they continue. The community should also be involved in all phases to ensure that they are planned and implemented with the special needs of the teenagers in the community in mind.

A multi-disciplinary intersectoral team approach should be fostered which should include all the stakeholders and interested parties involved in the well-being of teenagers and teenage mothers.

The recommendations focus on enhancing the teenagers' quality of life and on issues to be addressed by future research projects.

\section{Enhancing teenagers' life in Swaziland}

Various persons and institutions reportedly failed to provide knowledge and skills to teenagers to make informed choices about their future lives. The various stakeholders should therefore take the necessary steps to rectify this problem.

\section{The role of government}

The government should ensure that legislation, policies, services and manpower are available to provide the teenagers with knowledge about contraception and with the ability to access contraceptive services should they wish to do so. Education about sex and contraceptive issues should be provided to school children by the time they reach the age of 11 , as that was the reported mean age for menarche. Specific policies should be compiled and implemented at clinic level to enable teenagers to acquire and use contraceptives effectively. Teenagers should also be knowledgeable about emergency contraceptives. Long-term problems of teenage mothers in the Hho-Hho region of Swaziland can be addressed by assisting them to complete their education.

\section{The role of the health services}

The health services can play a major role in the prevention of pregnancies and in facilitating motherhood 
among the teenagers. These services already exist in the southern Hho-Hho region of Swaziland, but they can improve their service delivery by:

- addressing the under-utilisation of contraceptive services by teenagers;

- visiting teenage mothers who default on clinic visits;

- organising teenager-friendly services over weekends;

- visiting schools and youth clubs to share information about puberty, sexual issues, pregnancy and contraception (including the use of condoms);

- supplying condoms at strategic places;

- counselling teenage mothers about contraceptives and parenting skills; and

- organising clubs for teenage mothers where they could share their problems and jointly try to find solutions for them.

\section{The role of teachers}

As the child is in the company and care of the teacher for the largest part of the day, the teachers should make the most of the opportunity to educate and support the teenagers in school. The teachers should:

- offer sex education in school or get experts to do so;

- motivate teenagers to develop their talents, knowledge and skills in order to obtain the best education possible as a means to improving their individual financial and social status;

- enable pregnant teenagers to attend school as long as possible and to return to school as soon after their deliveries as possible; and

- motivate pregnant teenagers to complete their education in spite of numerous challenges.

\section{The role of the communities}

A high incidence of teenage pregnancies in any community could indicate that the community malfunctions as such.

- The community as a whole needs to talk to their children about sexual issues before the onset of menarche - from approximately the age of 10 .

- Church officials should visit the teenage mothers and counsel them about their needs and help them and their families to find solutions to their problems. Teenage mothers need to be invited to rejoin their previous church activities to reduce their feelings of isolation and alienation.
- The members of the community could establish crèches attached to schools to enable the mothers to feed their infants and to attend school. The government should subsidise such childcare facilities to the ultimate benefit not only of the teenage mothers and their children, but of the communities and even of the Swazi nation as a whole.

\section{Recommendations for further research}

- Research should be done to incorporate the views of family members, friends, and teachers to broaden and perhaps confirm the teenage mothers' perceptions reflected in this research report.

- Follow-up research should be done on this group of teenagers to determine how they and their children coped with these problems and what strengths they developed over time. This is essential as more than $20 \%$ of the babies delivered in the Hho-Hho area during 1996 had teenage mothers.

- Research could be done to determine the extent of the knowledge of teenage mothers on sexual matters and other aspects such as the prevention of HIV/AIDS.

- Future researchers should gain access to the teenage mothers' obstetric records to verify reports about physical conditions of these mothers and their babies.

- Quantitative research could be done on the same topic to determine the extent of the problems experienced by the teenage mothers.

- Research could be conducted on the health seeking behaviours of teenagers in the southern HhoHho region of Swaziland.

- Research is necessary for the development of strategies to involve parents and teachers in sex education.

- Sexual education programmes for school children of all ages (commencing prior to the age of 11) should be developed, implemented and tested.

\section{CONCLUSIVE REMARKS}

The teenage mothers in the Hho-Hho region of Swaziland felt that their parents, teachers and health care personnel failed to support them. They believed their sexual partners, peers and the television who promised them the world and a happy and romantic 
life, but once they were pregnant no support was forthcoming. They ended up feeling old and unhappy with compromised futures for themselves and their children.

However, the problems encountered by teenage mothers in Swaziland need to be addressed within the patriarchal cultural context still reigning in that country. "The scale of equality is especially out of balance in our imbalanced Swaziland. The side marked 'woman' is weighed down with responsibility while the side marked 'man' rides high with power" (Dlamini, 2000:82).

\section{BIBLIOGRAPHY}

ARETAKIS, D 2000: Teen pregnancy (in: STANHOPE, M \& LANCASTER, J 2000: Community and public health nursing; $5^{\text {th }}$ edition. St Louis: CV Mosby, pp. 684-701).

BABBIE, E; MOUTON, J; VORSTER, P \& PROZESKY, B 2001: The practice of social research. Cape Town: Oxford University Press.

BOULT, BE \& CUNNINGHAM, PW 1992: Black teenage pregnancy: an African perspective. Journal of Adolescence and Youth, 3:303309.

BURNS, N \& GROVE, SK 2001: The practice of nursing research: conduct, critique and utilization; $4^{\text {th }}$ edition. Philadelphia: WB Saunders.

DE VOS, AS; STRYDOM, H; FOUCHÉ, CB; POGGENPOEL, M \& SCHURINK, EM 1998: Research at grass roots. A primer for the caring professions. Pretoria: Van Schaik.

DLAMINI, S 2000: Reaction to patriarchal codes among emaSwati (in: MALHERBE, J; KLEIJWEGT, M \& KOEN, E 2000: Women, society and constraints: a collection of South African gender studies. Pretoria: University of South Africa).

HALLERSTEDT, WL; PIRIE, PL \& ALEXANDER, GR 1995: Adolescent parity and infant mortality, Minnesota: 1980-1988. American Journal of Public Health, 85(8):1139-1142.

MOORE, KA; DRISCOLL, AK \& LINDBERG, LD 1998. A statistical portrait of adolescent sex, contraception and childbearing. Washington DC: National Campaign to Prevent Teen Pregnancy. NORD, CW 1992. Consequences of teenage parenting. Journal of School Health, 62(7):310.

ORAL ROBERTS UNIVERSITY, ANNA VAUGH SCHOOL OF NURSING 1990: Self-study report, submitted to the Council of Baccalaureate and Higher Degree Programs, National League for Nursing, August 1990. Volume I - Narrative by Criteria. Tulsa: Oklahoma, 13:136-142.

SWAZILAND MOTHERHOOD AUDIT REPORT 1997: Mbabane: 